\title{
Propensity for DNA Damage in Psoriasis Patients Genotyped for Two Candidate Genes
}

\author{
G. Gandhi ${ }^{1 *}$, Premjot Singh Girgila², Ramesh K. Aggarwal ${ }^{3}$ and Brinderjit Singh Buttar ${ }^{1}$
}

${ }^{1}$ Department of Human Genetics, Guru Nanak Dev University, Amritsar, Punjab, India

${ }^{2}$ Formerly at Skin and T.B. Ward, Sri Guru Ram Das Charitable Hospital, Amritsar, Punjab, India

${ }^{3}$ Molecular Genetics Lab., Centre for Cellular and Molecular Biology, Hyderabad, India

\begin{abstract}
Studies assessing genetic damage and its association with disease-candidate genes in patients belonging to geographically distinct populations are scanty. The present study evaluated DNA damage using the alkaline Single Cell Gel Electrophoresis assay in peripheral blood leukocytes of Psoriasis Punjabi Patients on systemic-topical therapy who had been genotyped for two disease-candidate genes (HLA-C, human leukocyte antigen and the coiled-coil alpha-helical rod protein 1(CCHCR1). Genetic damage was disease gene-influenced as homozygous mutants for CCHCR1 Exon 4 site $386^{*}(\mathrm{C} \rightarrow \mathrm{T})$ and heterozygous mutants for $404^{*}(\mathrm{C} \rightarrow \mathrm{T})$ alleles had significantly more damage $(\mathrm{p}<0.05)$ compared to respective homozygous wild types. The arginine to tryptophan substitution alters the protein, triggering keratinocyte proliferation and probably inflammation/ oxidative stress. This along with drug-treatment probably caused the observed DNA damage. Population sub-groups had no within group differences but larger sizes can explore this possibility. Studies of this type can provide disease-gene-damage prone information for exploring DNA-safe therapeutics.
\end{abstract}

Keywords: Genetic damage; Gene association; Population subgroups

\section{Background}

Studies for associations between polymorphisms of candidate disease genes and genetic damage in geographically defined populations have not come to attention. Such studies can explore ethnic and racial differences in disease as well as propensity for DNA damage since the latter is an early indicator of carcinogenesis. Assessment of patients for genetic damage can assist in its management. Psoriasis, an immune-mediated inflammatory skin disease requiring long term treatment, affecting $2-3 \%$ of the population [1] with varying ethnicfrequency [2], mediated via genetic-environmental factors, causes keratinocyte hyperproliferation, inflammatory response [3] with an impaired oxidant/antioxidant status [4-6] which is damaging to proteins, lipids and DNA. Patients with/without various treatment modalities have been assessed for genetic damage [7-11] but none on both, systemic and topical treatments which is a regular, local prescription. Therefore DNA damage was investigated in peripheral blood leukocytes (PBL) of patients applying coal tar ointment and taking cyclosporine and/or Methotrexate using the alkaline single cell gel electrophoresis (SCGE) assay which assesses DNA strand breakage at cell level [12]. Patients were genotyped (unpublished work) for polymorphisms in two candidate genes: coiled-coil alpha-helical rod (CCHCR1) protein 1 (exons 4 and 10) and HLA-C region (SNPn7 and SNPn9) as their proteins are involved in manifestation of Psoriasis. CCHCR1 protein is differently expressed in lesional psoriatic skin with a role in keratinocyte proliferation [13] and HLA-C protein levels are increased in plaque psoriasis skin [14].

\section{Questions Addressed}

As propensity for genetic disease is ethnicity-dependent and as susceptibility for genomic insult has an association with metabolic genotypes, there could also be an association underlying disease gene-specificity and genetic damage. With this hypothesis and in view of cited literature, Psoriasis patients on systemic and topical therapy, already genotyped for some polymorphisms of CCHCR1 gene and HLA-C region, were assessed for DNA damage (pre-cancerous lesions) in order to correlate the level of genetic damage, if any, with their genotypic status, population sub-group besides routine variables. To the best of our knowledge, no such studies have been reported, at least not in Psoriasis patients from this region.

\section{Experimental Design}

Patients and healthy, matched controls participated after voluntary, written informed consent and study's institutional ethical clearance. Disease history, demographic information and pedigree were recorded on a questionnaire. PBL from genotyped patients were processed for DNA damage by alkaline SCGE assay [15] except use of local chemicals and silver staining. Under electrophoresis, breaks in the super coiled DNA migrate towards the anode and appear as a comet indicative of DNA damage. Coded slides were visually scored at $400 \mathrm{X}$. DNA migration was measured using a calibrated ocular micrometer and cells were graded into categories based on tail length. Arbitrary score, damage frequency (DF) and damage index (DI) were calculated [16] as mean \pm S.E.M. Mann-Whitney U test was applied for significance of DNA damage. Chi-square $\left(\chi^{2}\right)$ test compared attributes of patients and controls and their cells in different damage categories. Regression analysis, analysis of variance and odds ratio at $95 \%$ confidence interval were performed for confounders of DNA damage. Values were taken significant at $\mathrm{p} \leq 0.05, \mathrm{p}<0.01$ and $\mathrm{p}<0.001$. All analysis was done using SPSS (version 10.0).

\section{Results}

Characteristics of patients and matched controls are given in

*Corresponding author: G. Gandhi, Department of Human Genetics, Guru Nanak Dev University, Amritsar 143 005, India, Tel: +91-183-2258802-09 Extn. 3444; Fax: +91-183-2258820; Email: gandhig07@hotmail.com

Received November 13, 2010; Accepted December 04, 2010; Published December 06, 2010

Citation: Gandhi G, Girgila PS, Aggarwal RK, Buttar BS (2010) Propensity for DNA Damage in Psoriasis Patients Genotyped for Two Candidate Genes. J Carcinogene Mutagene 1:112. doi:10.4172/2157-2518.1000112

Copyright: @ 2010 Gandhi G, et al. This is an open-access article distributed unde the terms of the Creative Commons Attribution License, which permits unrestricted use, distribution, and reproduction in any medium, provided the original author and source are credited. 
Citation: Gandhi G, Girgila PS, Aggarwal RK, Buttar BS (2010) Propensity for DNA Damage in Psoriasis Patients Genotyped for Two Candidate Genes. J Carcinogene Mutagene 1:112. doi:10.4172/2157-2518.1000112

Page 2 of 3

\begin{tabular}{|c|c|c|c|c|c|c|c|c|}
\hline & \multirow[b]{2}{*}{ Allele } & \multirow[b]{2}{*}{ Genotype } & \multicolumn{3}{|c|}{ PATIENTS } & \multicolumn{3}{|c|}{ CONTROLS } \\
\hline & & & DI士 S.E.M. (n) & DF \pm S.E.M. (n) & $\begin{array}{l}\text { Mean DNA migration } \\
\text { length } \pm \text { S.E.M. }(n)\end{array}$ & DI士 S.E.M. (n) & DF \pm S.E.M. (n) & $\begin{array}{l}\text { "Mean DNA migration } \\
\text { length } \pm \text { S.E.M. (n) }\end{array}$ \\
\hline \multirow{9}{*}{$\begin{array}{l}\text { HLA-C } \\
\text { region }\end{array}$} & \multirow{3}{*}{$\begin{array}{l}22222^{*} \\
(G \rightarrow A)\end{array}$} & GG & $28.38^{\star \star \star} \pm 1.79(12)$ & $55.23^{* * *} \pm 3.28(12)$ & $37.51^{* * *} \pm 1.56(12)$ & $4.88 \pm 1.28(9)$ & $11.77 \pm 2.59(9)$ & $9.38 \pm 1.94(9)$ \\
\hline & & GA & $28.41^{* * *} \pm 1.94(16)$ & $55.29^{* \star *} \pm 3.62(16)$ & $33.78^{\star * *} \pm 2.60(16)$ & $6.75 \pm 2.56(4)$ & $13.50 \pm 5.12(4)$ & $12 . .29 \pm 4.36(4)$ \\
\hline & & AA & $33.42 * \pm 2.12(7)$ & $62.85^{\star} \pm 3.17(7)$ & $33.41^{*} \pm 3.49(7)$ & $6.00 \pm 1.00(2)$ & $12.00 \pm 2.00(2)$ & $9.07 \pm 0.68(2)$ \\
\hline & \multirow{3}{*}{$\begin{array}{l}22333^{*} \\
(A \rightarrow G)\end{array}$} & AA & $28.25^{\star \star} \pm 1.95(12)$ & $54.83^{* * *} \pm 3.54(12)$ & $36.92^{* * *} \pm 1.58(12)$ & $10.66 \pm 5.10(9)$ & $11.33 \pm 2.78(9)$ & $8.79 \pm 2.17(9)$ \\
\hline & & AG & $28.31^{* * *} \pm 2.06(16)$ & $55.12^{\star * \star} \pm 3.85(16)$ & $33.86^{\star * *} \pm 2.77(16)$ & $6.75 \pm 2.56(4)$ & $13.50 \pm 5.12(4)$ & $12.29 \pm 4.36(4)$ \\
\hline & & GG & $33.57^{*} \pm 1.70(7)$ & $62.85^{*} \pm 3.17(7)$ & $33.41^{*} \pm 3.49(7)$ & $6.00 \pm 1.00(2)$ & $12.00 \pm 2.00(2)$ & $9.07 \pm 0.68(2)$ \\
\hline & \multirow{3}{*}{$\begin{array}{l}24118^{*} \\
(T \rightarrow C)\end{array}$} & TT & $28.90^{* * *} \pm 2.01(11)$ & $56.18^{* * *} \pm 3.59(11)$ & $36.76^{\star * *} \pm 1.72(11)$ & $9.00 \pm 3.60(13)$ & $11.07 \pm 2.28(13)$ & $8.69 \pm 1.77(13)$ \\
\hline & & TC & $27.72 \pm 1.87(18)$ & $53.88 \pm 3.53(18)$ & $34.02 \pm 2.47(18)$ & $9.00 \pm 0.00(1)$ & $18.00 \pm 0.00(1)$ & $17.56 \pm 0.00$ \\
\hline & & CC & $34.83 \pm 1.88(6)$ & $65.33 \pm 2.34(6)$ & $33.66 \pm 4.12(6)$ & $9.00 \pm 0.00(1)$ & $18.00 \pm 0.00(1)$ & $15.79 \pm 0.00(1)$ \\
\hline \multirow{9}{*}{$\begin{array}{l}\text { CCHCR1 } \\
\text { gene }\end{array}$} & \multirow{3}{*}{$\begin{array}{l}386^{*} \\
(\mathrm{C} \rightarrow \mathrm{T})\end{array}$} & CC & $26.09^{* * \star a} \pm 2.02(11)$ & $50.36^{* \star \star a} \pm 3.51(11)$ & $32.83^{* * \star a} \pm 2.38(11)$ & $9.28 \pm 3.32(14)$ & $9.28 \pm 3.32(14)$ & $9.86 \pm 1.82(14)$ \\
\hline & & CT & $29.40 \pm 1.59(21)$ & $57.40 \pm 3.06(21)$ & $36.31 \pm 2.11(21)$ & $5.00 \pm 0.00(1)$ & $10.00 \pm 0.00(1)$ & $8.39 \pm 0.00(1)$ \\
\hline & & TT & $37.00^{a} \pm 2.64(3)$ & $66.66^{\mathrm{a}} \pm 1.33(3)$ & $36.37^{a} \pm 5.66(3)$ & - & - & - \\
\hline & \multirow{3}{*}{$\begin{array}{l}404^{*} \\
(C \rightarrow T)\end{array}$} & CC & $25.66^{* * * \mathrm{~b}} \pm 1.84(9)$ & $49.33^{* * * \mathrm{~b}} \pm 2.84(9)$ & $31.32^{\star \star \star} \pm 2.60(9)$ & $9.28 \pm 3.32(14)$ & $12.14 \pm 2.21(14)$ & $9.86 \pm 1.82(14)$ \\
\hline & & $\mathrm{CT}$ & $30.30^{\mathrm{b}} \pm 1.70(20)$ & $59.20^{\mathrm{b}} \pm 3.21(20)$ & $35.07 \pm 2.05(20)$ & $5.00 \pm 0.00(1)$ & $10.00 \pm 0.00(1)$ & $8.39 \pm 0.00(1)$ \\
\hline & & TT & $31.50 \pm 3.41(6)$ & $58.66 \pm 5.35(6)$ & $39.24 \pm 3.85(6)$ & - & - & - \\
\hline & \multirow{3}{*}{$\begin{array}{l}1364^{*} \\
(T \rightarrow C)\end{array}$} & TT & $28.01^{* * *} \pm 4.27(10)$ & $56.20^{* \star *} \pm 5.92(10)$ & $38.14^{* * *} \pm 3.61(10)$ & $6.40 \pm 1.39(10)$ & $12.80 \pm 2.78(10)$ & $10.83 \pm 2.22(10)$ \\
\hline & & TC & $30.31^{* * *} \pm 1.47(17)$ & $59.12^{\star \star \star} \pm 2.57(17)$ & $34.64^{* * *} \pm 1.93(17)$ & $5.25 \pm 1.93(4)$ & $10.50 \pm 3.86(4)$ & $7.63 \pm 3.25(4)$ \\
\hline & & CC & $25.60 \pm 2.37(8)$ & $10.00 \pm 0.00(8)$ & $30.00 \pm 4.23(8)$ & $50.00 \pm 0.00(1)$ & $10.00 \pm 0.00(1)$ & $7.55 \pm 0.00(1)$ \\
\hline
\end{tabular}

${ }^{* * *}$ Very highly significant $(p \leq 0.001),{ }^{* *}$ highly significant $(p \leq 0.01)$, *significant $(p \leq 0.05)$ when compared to parallel control groups (Mann Whitney $-U$-test)

***a Very highly significant when compared to parallel control group $(p<0.001)$ and significant $(p<0.05)$ within patient group $\left(386^{*}(C \rightarrow T)\right.$ Homozygous wild type patient group vs Homozygous mutant patient group; $p \leq 0.05$ ) (Mann Whitney -U-test)

$\star * \star b$ Very highly significant when compared to parallel control group $(\mathrm{p}<0.001)$ and significant $(\mathrm{p}<0.05)$ within patient group $\left(404^{*}(\mathrm{C} \rightarrow T)\right.$ Homozygous wild type patient group vs Heterozygous mutant patient group; $p \leq 0.05$ ) (Mann Whitney -U-test)

DI-Damage index; DF- Damage frequency; \$-Calculated as an average of individual DNA migration lengths in that group;

Table 1: HLA-C and CCHCR1 genotypes and DNA damage in Psoriasis patients and controls.

supplementary material (Table S1, Table S2). DNA migration length, DI and DF were significantly elevated $(p<0.05, p<0001)$ in patients compared to controls (Table 1). Patients homozygous for CCHCR1 $386^{*}(\mathrm{C} \rightarrow \mathrm{T})$ mutant allele and those heterozygous for $404^{*}(\mathrm{C} \rightarrow \mathrm{T})$ allele had significantly $(\mathrm{p}<0.05)$ more DNA damage than respective homozygous wild types. Homozygous mutants of these alleles in controls were lacking. Comet categories $1-3$ were also significantly higher $(\mathrm{p}<0.05$; Table S3). Multiple regression analysis revealed methotrexate-coal tar-cyclosporine combination $(\mathrm{p}=0.041)$, treatment time $(\mathrm{p}=0.045)$ and CCHCR $1386^{*}(\mathrm{C} \rightarrow \mathrm{T})$ allele association $(\mathrm{p}=0.021)$ with DNA damage in patients. Though Jat Sikh patients had more damage, there were no significant endogamous-group differences and damage in each group was significant from respective controls: Jat Sikhs at $p \leq 0.001$, Brahmins at $p \leq 0.01$, Ramgarhia and Majbi Sikhs each at $p \leq 0.05$. Early onset patients ( $<40 y$, type I) had significant difference $(p=0.004)$ compared to late on-set $(\geq 40 y$, type II) but with no gender differences (Table $S 4)$. In vulgaris $(\mathrm{p}=0.000)$ and palmo-plantar $(\mathrm{p}=0.002)$ types, damage was higher from controls but not from each other (Table S5). Methotrexate ( $2.5 \mathrm{mg} /$ week), coal tar application (5.3\%; once daily) with/without cyclosporine $(25 \mathrm{mg} /$ week) for $2-27 y$ caused significant damage $(\mathrm{p}<0.001)$ as did treatment duration but non-significantly (Table S6). Newly diagnosed patients $(n=3)$ also had more damage compared to controls but less from treated group.

\section{Conclusions}

DNA migration length, DF and DI reflect cellular events manifesting from DNA strand breaks. Propensity for genetic damage was disease gene-influenced as homozygous mutants for CCHCR1 Exon 4 site $386 \%(C \rightarrow T)$ and heterozygous mutants for $404 \%(C \rightarrow T)$ alleles had significantly more damage $(\mathrm{p}<0.05)$ compared to their respective homozygous wild types. The CCHCR1 protein plays a role in keratinocyte biology and in malignant transformation [17] and the CC to TT mutant change in its two SNPs could be altering the secondary structure from the wild type protein as tryptophan substitutes arginine [18] probably provoking an inflammatory/oxidative response and promoting DNA damage as observed in the mutant homozygous/ heterozygous patients but this requires confirmation. In Chinese and Finnish patients with these reported SNPs $[18,19]$, genetic damage assessment can provide insights for disease gene- susceptibility and DNA damage. Punjab people are mostly Sikhs and Hindus by religion but belong to different endogamous groups. These patients had comparable damage but larger samples can explore damage susceptibility/resistance.

The observed DNA damage probably resulted from diseaseinduced oxidative stress with a potentiating effect of the therapeutics. The CCHCR1 allele product may too be modulating some aspects of DNA damage. Since genetic damage is prequel to neoplasia, increased risk in Psoriasis patients exists for developing cancer even in nontarget cells in addition to developing "systemic" co-morbidities [20] and basal cell carcinoma. To our knowledge this is a first study of its kind. Such population-specific disease-gene and genetic damage association studies can provide disease-damage susceptibility/ resistance information which can be useful for exploring targetspecific DNA- safe therapeutics.

\section{References}

1. Bowcock AM, Krueger JG (2005) Getting under the skin: the immunogenetics of psoriasis. Nat Rev Immunol 5: 699-711.

2. Elder JT, Nair RP, Henseler T, Jenisch S, Stuart P, et al. (2001) The genetics of psoriasis 2001: the odyssey continues. Arch Dermatol 137: 1447-1454.

3. Griffiths CE, Powles AV, Leonard JN, Fry L, Baker B S, et al. (1986) Clearance of psoriasis with low dose cyclosporin. Br Med J 293: 731-732.

4. Briganti S, Picardo M (2003) Antioxidant activity, lipid peroxidation and skin diseases. What's new. J Eur Acad Dermatol Venereol 17: 663-669.

5. OkayamaY (2005) Oxidative stress in allergic and inflammatory skin diseases. Curr Drug Targets Inflamm Allergy 4: 517-519.

6. Zhou Q, Mrowietz U, Rostami-Yazdi M (2009) Oxidative stress in the pathogenesis of psoriasis. Free Radic Biol Med 47: 891-905.

7. Moller P, Kundsen LE, Frentz G, Dybdahl M, Wallin H, et al. (1998) Seasonal variation of DNA damage and repair in patients with non-melanoma skin cancer and referents with and without psoriasis. Mutat Res 407: 25-34.

8. Borska L, Fiala Z, Smejkalova J, Hamakova M, Kremlacek J (2004) Possible genotoxic risk of combined exposure to pharmaceutical coal tar and UV-B radiation. Cent Eur J Public Health Suppl 12: S14-S15.

9. Fiala Z, Borska L, Pastorkova A, Kremlacek J, Cerna M, et al. (2006) Genotoxic effect of Goeckerman regimen of psoriasis Arch Dermatol Res 298: 243-251. 
Citation: Gandhi G, Girgila PS, Aggarwal RK, Buttar BS (2010) Propensity for DNA Damage in Psoriasis Patients Genotyped for Two Candidate Genes. J Carcinogene Mutagene 1:112. doi:10.4172/2157-2518.1000112

Page 3 of 3

10. Borska L, Andrys C, Krejsek J, Hamakova K, Kremlacek J, et al. (2009) Plasma levels of $\mathrm{p} 53$ protein and chromosomal aberrations in patients with psoriasis treated with the Goeckerman regimen. Clin Exp Dermatol 34: e881-e883.

11. Borska L, Smejkalova J, Cerna M, Hamakova K, Kucera I, et al. (2010) Urinary mutagenicity and genotoxic risk in children with psoriasis after therapeutic exposure to polycyclic aromatic hydrocarbons and ultraviolet radiation. Mutat Res 696: 144-147.

12. Ündeğer U, Şahin TT, Yüksel O, Bostanc H, Kurukahvecioğlu O, et al. (2008) Assessment of DNA Damage in Peripheral Blood Lymphocytes From Patients with Benign and Malignant Thyroid Disorders. University Journal of the Faculty of Pharmacy 28: 1-14.

13. Lowes MA, Bowcock AM, Krueger JG (2007) Pathogenesis and therapy of psoriasis. Nature 445: $866-873$.

14. Carlen L, Sakuraba K, Stahle M, Sanchez F (2007) HLA-C expression pattern is spatially different between psoriasis and eczema skin lesions. J Invest Dermatol 127: 342-348

15. Singh NP, McCoy MT, Tice RR, Schneider EL (1988) A simple technique for quantitation of low levels of DNA damage in individual cells. Exp Cell Res 175 184-191.

16. Collins A, Ai-Guo M, Duthie SJ (1995) The kinetics of repair of oxidative DNA damage (strand breaks and oxidised pyrimidines) in human cells. Mutat Res 336: 69-77.

17. Suomela S, Elomaa O, Skoog T, Ala-aho R, Jeskanen L, et al. (2009) CCHCR1 is up-regulated in skin cancer and associated with EGFR expression. PLoS One 4: e6030.

18. Chang YT, Shiao YM, Chin PJ, Liu YL, Chou FC, et al. (2004) Genetic polymorphisms of the HCR gene and a genomic segment in close proximity to HLA-C are associated with patients with psoriasis in Taiwan. $\mathrm{Br} J$ Dermatol 150: 1104-1111.

19. Asumalahti K, Veal C, Laitinen T, Suomela S, Allen M, et al. (2002) Coding haplotype analysis supports HCR as the putative susceptibility gene for psoriasis at the MHC PSORS1 locus. Hum Mol Genet 11: 589-597.

20. Davidovici BB, Sattar N, Prinz JC, Puig L, Emery P, et al. (2010) Psoriasis and systemic inflammatory diseases: potential mechanistic links between skin disease and co-morbid conditions. J Invest Dermatol 130: 1785-1796. 